\title{
5 \\ Pulse and Pause: Researching the Economic Future of Northern and Remote Australia
}

\author{
Rolf Gerritsen
}

\section{Introduction}

With the current federal government interest in northern development (Australian Government, 2014), the opportunity supposedly exists both to position remote and Northern Australia for a prosperous and sustainable future and to make it a full participant in future Australian economic development. That outcome requires understanding of past developments to inform future assumptions and what they portend for Northern Australia. The nature of the past development of Northern Australia does not instil confidence that something will change that wellestablished pattern.

In the past, sudden rushes of optimism and investment were followed by decades of disappointment. Pearling rose and fell. Pastoralism rose and fell before establishing some equilibrium. Mining was characterised by brief 'booms'-mostly during the two World Wars-followed by slow 'busts', a pattern that recurred across remote Australia.

The future portends the likely erratic economic development of the region and the separate but continuing marginalisation and impoverishment of its Aboriginal population-features that provide particular challenges that set Northern Australia apart from the rest of the country. 
In Darwin in 1900, the South Australian public servants that administered its northern territory wore clothes imported from Singapore. They ate some Asian food and Darwin had far more Chinese residents than European/Australian ones. Live cattle were exported to Asia from northern ports, particularly from the Kimberleys. The combination of the postFederation policy of White Australia and governmental neglect (the north Queensland coastal area aside) reduced that Asian connection. In Darwin in 2000, or for that matter in Townsville or Broome, residents still wore clothes imported from Asia but they were wholesaled via Melbourne. After a post-World War I hiatus, live cattle exports to Asia resumed in the 1980s. In the period between, abattoirs across Northern Australia produced meat primarily for the domestic market. Asians were now in a minority of migrants (from overseas and from interstate Australia). But Asia was still the main market for most of Northern Australia's exports. But Asian imports bypassed the north, heading instead to the metropolitan ports of Southern and Eastern Australia. The economics of large-scale, long-range sea transport sidelined Northern Australia except for outward-bound cargoes of minerals.

Northern Australia has been enmeshed in a relationship with Asia almost since it was 'settled' and its resident Aborigines conquered. But the nature of that relationship has changed in ways that reflect the broader changes that have occurred in Australia over the last century. The economic relationship-agriculture, particularly sugar, the live cattle trade and some tourism aside-is now mediated through metropoles. As seen in the example of Northern Australians wearing clothes made in Asia but 'imported' via Melbourne.

This chapter begins an ongoing analysis of the economic development of Northern Australia that I will expand on in the future.

\section{Economic Development's History in the North}

Economic development in Northern Australia historically parallels the 'pulse and pause' model ecologists use to describe the natural biological systems of the region. Development occurs rapidly (the boom) and then pauses into stasis, often for many years. The second half of the nineteenth century saw a dramatic 'pulse' as industries such as mining, pastoralism and 
pearling irrupted into Northern Australia (as did agriculture, particularly sugar, on the Queensland coast). In the 1950s, pearling disappeared, destroyed by the plastic button. That industry was later resurrected in a more sustainable form as represented by the cultured pearl industry, a high-tech industry aiming at the luxury consumer goods market and not the mass markets of the past.

Miners, now so important, were also significant in the expanding frontier of the north in the nineteenth century. Gold rushes in the Palmer River area and at Halls Creek in the 1870s and 1880s introduced large (for the north) populations briefly into the area. Many other areas featured mining booms and busts. The World Wars stimulated mining, particularly for the tin, copper and wolfram that was integral to the war effort each time (Jones, 1987, Appendix 1). From the 1960s, the development of Mount Isa and, later, the northern bauxite industry at Weipa and Gove and the Pilbara iron ore province and Bowen Basin coal in Queensland meant that mining replaced pastoralism and sugar and became the dominant 'productivist' private sector industry in the north. In the 1970s, the Pilbara natural gas province emerged as part of this first post-war mining boom. Gold and other base metals also joined this boom in Western Australia (WA) and Queensland. The post-2002 boom actually (notwithstanding the popular hype about the 'two-speed' economy in the past decade) had less structural impact on the Australian economy than the 1960s-70s resource boom (Connolly \& Orsmond, 2011; Edwards, 2014). If anything, it consolidated the metropolitan heartlands. For example, Perth developed as the dominant centre for mining logistics and the provision of labour (via the fly-in/fly-out [FIFO] mechanism). For extractive industries, the Pilbara and the Northern Territory can now be considered as Perth's economic hinterland (Gerritsen, 2010).

After the rapid expansion of pastoralism from the 1880s to World War I, this industry has mostly paused. There have been brief revivals, as in the 1960s-70s with the Commonwealth beef road program and mechanisation and contractualisation to replace Aboriginal labour. This latter element was sped up by the equal wage case of 1967 but was underway before then. Essentially, pastoralists abandoned the labourintensive model of production because it was uneconomic and seen as a state-sponsored exploitative appropriation of 'cheap' Aboriginal labour. More recently, the industry has sustained itself (as before World War I) by live exports, although it appears some companies are interested in developing a more sophisticated model based on vertically integrated 
supply chains. So, after a break of 30 years, abattoirs may return to the north (AACo constructed and briefly operated one near Darwin). Governments have also enhanced the potential for pastoral lands to contribute to future economic diversification by increasingly allowing use-purpose variations of pastoral leases. This process has developmental advantages. It shifts development risk onto the private capital that will benefit from any successful diversification of production; it is small-scale and potentially sustainable and avoids expensive, publicly funded, 'white elephant' projects, such as the Ord River scheme and other recent wild proposals to make the north the 'food bowl of Asia'. With Asian food demand predicted to continue to grow strongly until 2040, the market situation is promising, particularly for tropical fruits, grains and oilseeds. Investment will increasingly come from an Asia concerned more about food security than profits. Nevertheless, with improved herd and water management, experts propose that beef exports could increase by 80 per cent within three decades (Deane, 2014).

Apart from along the maritime littoral of Queensland, agriculture has not driven economic development in the north. The east coast of Queensland has managed intensive development, initially around sugar, and features a density of large towns and cities that portend self-sustaining development. This region exhibits economic dynamics (coal mining aside) that make it distinct from the rest of Northern Australia. It has large service centres (e.g. Townsville, or Mackay for mining), industrial cities (Gladstone) and mixed services/tourism centres (e.g. Cairns). This region of Queensland now has about two-thirds of the population of Northern Australia. It is here and in Darwin that most Northern Australian population increases will occur. The rest of the region can expect stasis or slow population rises below the national average.

In the rest of Australia's north, large-scale agriculture has not been successful. In the 1950s and 1960s, large schemes, such as Humpty Doo rice, failed and the Ord River project has never repaid its capital cost. Agricultural development is often the political driver of northern development, but rarely has it been an economic driver. It seems that this is currently the case. There is a case for more intensive agriculture in the north but designed sustainably around small locally efficient production and not dependent on federal investment in dams for irrigated broad acre cropping. Horticulture and specialist tropical crops appear to have the 
most environmentally and economically sustainable prospects. They can target high-value niche markets (the burgeoning Asian middle class) and so overcome expensive transport costs.

\section{Recent Economic Development: The So-Called 'Two-Speed' Economy?}

The idea of Australia's two-speed economy that is driven from Northern Australia was fuelled by a recent gigantic investment boom in the construction of new mines and natural gas projects. This was accompanied until 2011 by a massive price rise for iron ore and coal, prices that recently have plummeted to nearer the long-term average and threaten much of the investment made during the boom. The novelty of the two-speed hypothesis, predicated on producing primary products to capitalise on rapid industrialisation in China, is overstated in two senses. Northern Australia's burgeoning resource extraction industries have been linked with Asian industrialisation since the 1960s, starting with Japan and then South Korea. The 1960s and '70s saw economic pulses in the north based on these industries. Because they saw the construction of new towns (mostly in the Pilbara), this initial phase had more impact on long-term northern development than the most recent boom/pulse of the first decade of this century. Second, the gross domestic product (GDP) share of mining during the 2002-11 boom did not expand faster than the general economy - so mining as a share of real GDP was the same in 2011 as in 2002 (Rayner \& Bishop, 2013).

The core features of Australia's so-called two-speed economy are the concentration of a growth industry's central management in a growth metropole (i.e. Perth), with much of the value added in the mining industry being created there and the demand for labour at the resourceproducing periphery. Although WA only employs 36 per cent of mining, including oil and gas, industry workers (Queensland employs 27 per cent and New South Wales 21 per cent), mostly in coal mining, it garners over 48 per cent of the mining industry's value added. Perth has become the epicentre of a wide range of resource extraction services companies engaged in support logistics, mining construction and design services, IT, finance, explosives and so on. Some of these, such as Leighton Holdings, Orica, Worley Parsons and Incitec, are now very large companies servicing resource extraction enterprises worldwide. These types of companies 
increased their share of nominal GDP from 3 per cent to 6.5 per cent during the recent minerals and energy investment boom (Rayner \& Bishop, 2013). Some (probably most) of them will survive the current 'pause' because of their international diversification. This is arguably the most significant development in the Australian economy since the economic restructuring of the 1980s restored Australian competitiveness and coincided with a shift to service industries and a long downturn in manufacturing.

In effect, Northern and remote Australia has become part of Perth's economic hinterland. Queensland is a little more complex because coal mining is serviced from a number of larger north-east coastal regional cities, like Mackay. Brisbane is not establishing itself as an economic services metropole in the same way as Perth.

The problem for Northern Australia is the poor multipliers into the region of this resource extraction industry. Remote Central and Northern Australia are probably going to be weakly coupled to this engine of Australian growth over the foreseeable future.

All this will be significant—socially, politically, and economically—if the 'super-cycle' of resource demand principally created by the industrialisation of China (and probably India) continues. At present, it looks that the familiar pulse and pause (or in mining industry parlance, boom and bust) pattern is in a pause (bust) phase. Mines are closing because they were constructed during the boom and so were expensive and the low current primary commodities prices cannot justify their relatively high cost of production. None of this is surprising if you are a Western Australian. The eastern goldfields of WA are littered with the remnants of (usually expensively constructed) public buildings that are all that remain of oncethriving gold mining towns - think Sandstone, Menzies, Cue, Yalgoo, etc. These towns were not resurrected during the recent gold mining boom, which used FIFO labour.

This pattern of economic development has features that impact on Northern Australian governments. WA's overambitious scheme to make Port Hedland and Karratha cities of 50,000 people is explicable by the demands of the WA Nationals 'Royalties for Regions' - a result of the 2002 state election. It is temporary. The reality is that there was relatively little public infrastructure provision during the last resource pulse; existing infrastructure was more intensively used (Bureau of Infrastructure, Transport and Regional Economics, 2014). The last pulse 
saw labour sourced from places other than the operation point of the resource extraction project. The resource extraction labour force is largely supplied by FIFO workers commuting from large towns and cities, not in remote or Northern Australia (Queensland has a variation of this in drivein/drive-out workers commuting from coastal cities to the coal mines of the Bowen and Galilee basins). Such arrangements are a consequence of how mining companies have developed new 'greenfields' projects (i.e. no longer providing a town to house workers because of the front-end costs and the associated exchange rate and interest rate risks) (Gerritsen, 2010, pp. 30-32). The provision of housing, education, health and other services for the workforce is left to the relevant state, territory or local governments. The extra costs of running a mine with FIFO labour comes off the Commonwealth's company tax receipts. So, FIFO makes eminent sense for mining companies; its only downside (for mining companies) is in exacerbating labour turnover. Governments have to worry about services, maintaining viable towns and relevant infrastructure, so they bear most of the social and fiscal costs of resource extraction.

The high cost of labour in the northern resource extraction industries means that mining companies will increasingly automate their operations. Driverless trucks and trains have already been introduced. Soon we will have mines run almost entirely by machines. Over the next two or three or so decades, mining output growth will not be matched by employment growth and FIFO will wane. The resource extraction industries will drive northern growth (in export-value terms) but not northern development. Here changes broadening the economy will be based in the metropoles, particularly Perth. The services industries (and possibly the military) will supply most future northern labour market and population growth and economic development.

So, future research must turn to the services sector to define growth possibilities. That does not mean that services will remain separate from resource extraction or agriculture. These industries can provide services opportunities, as indicated by the development of logistics and engineering services that accompanied the most recent resource pulse (boom) indicates. To grow current agricultural productivity requires a range of agronomic and soil science services (and finance, workforce training, etc. services). So, the services sector is where future labour and consumer markets will grow. The issue for Northern Australia (apart from the Queensland coastal cities and Darwin) is attracting labour to maintain services and economic viability. Overseas migration can be one means 
(Taylor et al., 2014). Principally, this remains an issue of amenityready access to goods and services and at reasonable prices (Department of Regional Development, 2013), which is difficult to supply to remote and small towns. Labour constraints will continue to be a problem for Northern Australia.

\section{Indigenous Aspects}

The economic development described above will have minimal beneficial elements for the Aborigines of remote and Northern Australia. Their well-known relative poverty, poor education and disconnect with the development of the larger Australian economy will—assuming current policy settings - probably get worse. Directly that is because Aborigines in remote and Northern Australia generally lack the skills or aptitudes that allow them to participate in the current economy. Even measures designed to benefit Aborigines mostly provide money to non-Aboriginal parties (Stoeckl et al., 2014). And it has been argued (Gerritsen \& Straton, 2007) that the assumptions on which government services are delivered misread how Aboriginal settlements operate.

That situation is partly a legacy of history. Aboriginal people were forcibly accommodated into the colonial system after the British conquest of Northern Australia during the second half of the nineteenth century. Mostly, Aborigines resided on missions and cattle stations and, more recently, on supposedly self-governing communities. The autarchic economy of these places collapsed in the 1970s. In the latter part of the twentieth century, governments attempted to start Aboriginal enterprises but, for various reasons, these were mostly failures (Gerritsen, 2006). They were replaced by various training/workfare schemes, which persist to the present. The problem of Aboriginal engagement with the northern economy is partly that they reside on remote, poorly equipped communities far from real 'markets'. This residential pattern was initially the direct result of missions and governments historically seeking to keep Aboriginal people from the corrupting and debasing influences of white settlements. Later, it came from legal changes creating various forms of rights in land and the consequent return of many Aboriginal people to their traditional lands. Arguably, their culture also inhibits Aboriginal involvement in capitalist market activities (Austin-Broos, 2006; McRae- 
Williams \& Gerritsen, 2010). In conventional human capital terms, Aborigines have not 'invested' in their human capital to become job-ready (e.g. Gregory, 2005).

Indigenous disadvantage will persist, partly because there are paradoxes between Aboriginal society and the demands of Australian polities. That which is sought is internally contradictory-the state is inchoate. For example, some advocates and some policies value and privilege Aboriginal connection to and ownership of land. This currently has generally negative implications for access to mainstream economic opportunities because of institutional barriers to Aborigines selling or leasing their land (plus Aboriginal unwillingness to do so).

Other public policies require Aboriginal involvement in the mainstream economy ('real jobs' and 'Closing the Gap'). This paradox is replicated in Aboriginal society, where there is widespread recognition of poverty and that only 'real' jobs can reduce that problem. At the same time, patterns of relatedness and demand sharing are valued by Aborigines, notwithstanding that they prevent the achievement of the individual advancement that is at the core of capitalist economic progress (AustinBroos, 2005; McRae-Williams \& Gerritsen, 2010).

If Aboriginal labour remains immobile (i.e. they continue residing in remote communities), then the economic costs of distance will be great and economically conventional Aboriginal economic engagement will struggle. A solution here proposed is to reconceptualise Northern Australian economies into sectors-the capitalist, the state, a communal sector and a philanthropic sector. These would interact in a multiplex economy. My multiplex economy model is a development from Altman's (2001) 'hybrid economy' model and is presented in Appendix 1.

As originally proposed (Gerritsen, 2006), a multiplex economy would see the continuation of primarily government-sponsored Aboriginal enterprise creation and the entry of some Aboriginal persons into formal employment (mostly in government services). For example, the Northern Territory government (supported by Commonwealth funding) has, or recently has had, enterprise initiatives in areas such as aquaculture, forestry and agribusiness, mining services, pastoralism and tourism. These enterprises may create several hundreds of jobs in the foreseeable future. Relations between Aborigines and the mining industry have long been problematic (Scambery, 2013). It appears that Aborigines have secured better personal outcomes from mines operating under native title and 
better community development outcomes from mines within the land rights jurisdiction of the Northern Territory (Stanley, 2010). However, current economic approaches are an incomplete answer to the endemic unemployment on northern remote Aboriginal settlements. The best way to create the thousands of jobs required to reduce Aboriginal unemployment to levels comparable to those of the rest of Australia is in the communal sector element of the multiplex economy. For example, traditional Aboriginal skills in land and fire management could be augmented by roles in biosecurity and biodiversity protection to create a natural resource management (NRM) economy that would be an integral part of the multiplex economy of remote Australia. At present, public investment (via Caring for Country programs) is low. In 2012, the Australian Government funded only 680 Indigenous ranger positions across 90 ranger groups nationally. So, currently there are only a few hundred 'jobs' here where there should be thousands. Some successful Aboriginal industries, notably the Indigenous arts industry, already builds successful economics on top of Indigenous cultural resources (Morphy, 2005), although that industry has problems with intellectual property (Altman et al., 2002) and related oversupply and quality issues (Rothwell, 2015). The philanthropic sector, an integral part of my evolving multiplex economy, can provide capital, expertise and a spur to governments to persist with investment.

What my current iteration of the multiplex economy model adds to the equation is the introduction of the philanthropic sector. This was suggested by previous work on rangeland conservation (Salmon \& Gerritsen, 2013). The condition of the Aborigines of Northern Australia attracts philanthropic attention. Increasingly, philanthropic foundations provide money for Aboriginal causes, like education and employment. The attempts by industry leaders to create 50,000 Aboriginal jobs in the mining industry, which has failed to date mostly because of the recent investment downturn, is a case in point. This philanthropy sectoral involvement (to my knowledge) has not been adequately documented but it is a potential core of any Aboriginal economic development in Northern Australia. It has two potentials, by its attention to spur/shame the efforts of governments and also as a positive bridge between the communal and capitalist/governmental sectors. Mapping out this interaction is an obvious subject for further research. 


\section{What do we need to know to make a multiplex economy work?}

Some of the research required for the multiplex economy has begun. Anthropologists and geographers have given us an understanding of Aboriginal land management (e.g. Baker et al., 2001). Traditional burning practices are now relatively well understood (Dyer et al., 2001; RussellSmith et al., 2009) and the basic parameters of sustainable Aboriginal use of native flora and fauna have been sketched out (Altman \& Whitehead, 2003). But there are large gaps in the research effort. Particular lacunae I will address here are in the demographic, economic and institutional realms. To some extent these raise inter-related questions.

If, to reduce unemployment, a communal land-based (or NRM) economy is to be encouraged, then it will be centred on dispersed outstation/ homelands settlements. Demographic research is required to determine the possibilities for future migration and settlement patterns. We know that Aborigines are highly mobile, within particular ranges (Memmott et al., 2006). But we do not know if the conventional economic development assumption (encouraged by some official policy) that urban drift is inevitable, probable, possible or even unlikely. We also do not know whether such migration is likely to be pervasive or even uniform, or whether that migration will occur in particular stages of the life cycle to be followed by reverse migration in later life. This knowledge requires more than just population movement surveys; we need to have a realistic view of underlying Aboriginal incentives and motivations.

Research (if not policy experience) has shown that the tension between 'work' and the web of kinship, ceremony and family incentives affects (conventional) economic behaviour (Austin-Broos, 2006; McRaeWilliams \& Gerritsen, 2010). In addition, basic economic research is required to determine the markets and production and marketing processes for the potential products of an Aboriginal NRM economy. The existing economic research relating to the value of land management and exotic flora and fauna control and other biosecurity issues is at present rudimentary. To it should be added research into enhanced possibilities for ecotourism and cultural tourism. The probable eventual emergence of carbon trading regimes will also have to be factored into the parameters for an Aboriginal NRM industry to emerge out of the welfare economy. In addition, the institutional/administrative rules and frameworks that 
will bound these communal activities, if they are to be assigned or achieve economic value, will have to be analysed. The implications of overelaborate accountability procedures and increasing interventions via mainstream non-government organisations are cases in point.

It appears that Aboriginal people are currently at the same sort of crossroads that marked the imposition of colonial control. If an alternative multiplex economy based on communal production and focused on natural resource-based activities is to emerge, it is important that the research that would allow this to happen is facilitated.

\section{Conclusions}

What can we expect of northern development in the next few decades? Intensified urbanisation is likely. The major Queensland coastal cities will continue to grow, driven by a services economy, and their hinterland towns will languish relatively. Like Darwin, they have become 'soak' cities. Thus, the post-World War II growth pattern (Bureau of Infrastructure, Transport and Regional Economics, 2014) will continue, except that Gladstone will do better than Bundaberg and Rockhampton (Mackay, essentially a mining construction supply city, has suffered a postconstruction bust). Darwin, the only other major northern centre, will continue to grow but the long-term driver will not be resource extraction but new Commonwealth governmental expenditure, possibly on national security and biosecurity. In WA, neither Karratha nor Port Hedland, notwithstanding former premier Barnett's stated intentions to make them cities of 50,000 persons each, is likely to match the growth of Darwin (or Townsville, Gladstone, etc.). The economics of agglomeration is against them. The continued growth of Darwin will exacerbate the problem of urban bias in the Northern Territory's public policy that leads to under-funded and under-performing services to Aboriginal communities (Gerritsen, 2010).

Indigenous disadvantage, particularly in economic terms, will persist. That is, unless research to develop new forms of economy_perhaps something like Altman's (2001) hybrid economy or my multiplex economy-in which Aboriginals can and will participate. Aboriginal advancement (even its definition) remains Northern Australia's most wicked problem.

There are core problems in Northern Australia that merit serious research, including: 
- the environment-how to manage it to achieve not just conservation but sustainable economic growth and broadened economic opportunities. This requires new notions of the 'economic' and the application of more science to agricultural/horticultural development

- the population-how to retain residents and immigrants and educate them to produce a forward-looking labour market that can respond to new opportunities, especially in services industries and, crucially, how to produce an economy for the Aboriginal population

- infrastructure-how to create the infrastructure that makes Northern Australia both a worthwhile place to live (education, health and cultural and recreational infrastructure) and economically efficient (physical infrastructure).

These are the issues that researchers and policymakers interested in the economic development of Northern Australia must consider.

\section{Appendix 5.1: Conceptualising the Multiplex Economy of Northern Australia}

\begin{tabular}{|c|c|c|c|c|}
\hline $\begin{array}{l}\text { Production } \\
\text { factors }\end{array}$ & State & Communal & Capitalist & Philanthropic \\
\hline Ecosystem & Regulation & Natural balance & Sustainability & Support \\
\hline Technology & Promote & Traditional & Market (C-B) & $\begin{array}{l}\text { Support/ } \\
\text { Provide }\end{array}$ \\
\hline Knowledge & Research & Traditional & Applied/Adaptive & $\begin{array}{l}\text { Support/ } \\
\text { Provide }\end{array}$ \\
\hline $\begin{array}{l}\text { Property } \\
\text { rights }\end{array}$ & Regulation & Communal & $\begin{array}{l}\text { Individual } \\
\text { markets/profits }\end{array}$ & Support \\
\hline Fiscal flows & Taxes/grants & Dependence & Tax expenditure & Donations \\
\hline Capital & Infrastructure & Communal land & $\begin{array}{l}\text { Market } \\
\text { investment }\end{array}$ & Provide \\
\hline Labour & $\begin{array}{l}\text { Regulation/ } \\
\text { employer }\end{array}$ & Family & Individual & Support \\
\hline \multicolumn{5}{|c|}{ Values system } \\
\hline & Promote & $\begin{array}{l}\text { Family/ } \\
\text { traditional }\end{array}$ & Applied/Adaptive & Altruism \\
\hline & Sustainability & & Growth & \\
\hline
\end{tabular}




\section{References}

Altman, J. (2001). Sustainable development options on Aboriginal land: The hybrid economy in the twenty-first century (Centre for Aboriginal Economic Policy Research, Discussion Paper No. 226). Canberra, ACT: ANU.

Altman, J., Hunter, B. \& Wright, F. (2002). Indigenous visual arts industry. Competition and consumer issues for Indigenous Australians. Canberra, ACT: Australian Competition and Consumer Commission.

Altman, J. \& Whitehead, P. (2003). Caring for country and sustainable Indigenous economic development opportunities. Constraints and innovation (Centre for Aboriginal Economic Policy Research, Working Paper 20/2003). Canberra, ACT: ANU.

Austin-Broos, D. (2005). Introduction. In D. Austin-Broos \& G. MacDonald (Eds), Culture, economy and governance in Indigenous Australia (pp. 1-5). Sydney, NSW: Sydney University Press.

Austin-Broos, D. (2006). 'Working for' and 'working' among Western Arrente in central Australia. Oceania, 76(1), 1-15.

Australian Government. (2014). Green paper on developing Northern Australia. Canberra, ACT: Department of the Prime Minister and Cabinet. Retrieved from www.industry.gov.au/sites/default/files/2019-09/green-paperon-developing-northern-australia.pdf

Baker, R., Davies, J. \& Young, E. (2001). Contemporary Indigenous management of Australia's lands and coastal regions. Melbourne, Vic.: Oxford University Press.

Bureau of Infrastructure, Transport and Regional Economics. (2014). The evolution of Australian towns (Report 136). Canberra, ACT: Department of Infrastructure and Regional Development.

Connolly, E. \& Orsmond, D. (2011). The mining industry: From bust to boom. In The Australian economy in the 2000s. Sydney, NSW: Reserve Bank of Australia.

Deane, P. (2014). Molehill to mountain: Agriculture in Northern Australia. Melbourne, Vic.: ANZ Bank Co.

Department of Regional Development. (2013). Regional price index 2013. Perth, WA: Department of Regional Development, Government of Western Australia. 
Dyer, R., Jacklyn, P., Partridge, I., Russell-Smith, J. \& Williams, D. (2001). Savanna burning: Understanding and using fire in Northern Australia. Darwin, NT: Tropical Savannas CRC.

Edwards, J. (2014). Beyond the boom. A Lowy Institute paper. Melbourne, Vic.: Penguin Books.

Gerritsen, R. (2006). A resilient future for Northern Australian? People, economics and policy issues. In N. Stacey, G. Boggs, B. Campbell \& W. Steffan (Eds), Prepare for impact! When people and the environment collide in the tropics (pp. 4-10). Darwin, NT: Charles Darwin University Press.

Gerritsen, R. (2010). A post-colonial model for north Australian political economy: The case of the Northern Territory. In R. Gerritsen (Ed.), North Australian political economy: Issues and agendas (pp. 18-40). Darwin, NT: Charles Darwin University Press.

Gerritsen, R. \& Straton, A. (2007). Coping with a tragedy of the Australian Aboriginal common. In A. Smajgl \& S. Larson (Eds), Sustainable resource use: Institutional dynamics and economics (pp. 162-176). London, England: Earthscan.

Gregory, R. (2005). Between a rock and a hard place: Economic policy and the employment outlook for Indigenous Australians. In D. Austin-Broos \& G. MacDonald (Eds), Culture, economy and governance in Indigenous Australia (pp. 135-150). Sydney, NSW: Sydney University Press.

Jones, T. (1987). Pegging the Northern Territory: A history of mining in the Northern Territory, 1870-1946. Darwin, NT: Northern Territory Government Printer.

McRae-Williams, E. \& Gerritsen, R. (2010). Mutual incomprehension: The cross cultural domain of work in a remote Australian Aboriginal community. International Indigenous Policy Journal, 1(2). doi.org/10.18584/iipj.2010. 1.2.2

Memmott, P., Long, S. \& Thomson, L. (2006). Indigenous mobility in rural and remote Australia (Final Report No. 90). Melbourne, Vic.: Australian Housing and Urban Research Institute. Retrieved from www.ahuri.edu.au/research/ final-reports $/ 90$

Morphy, H. (2005). Indigenous art as economy. In D. Austin-Broos \& G. MacDonald (Eds), Culture, economy and governance in Indigenous Australia (pp. 19-28). Sydney, NSW: Sydney University Press.

Rayner, J. \& Bishop, R. (2013). Industry dimensions of the resource boom: An inputoutput analysis. Sydney, NSW: Reserve Bank of Australia. 
Rothwell, N. (2015, 2-3 May). Wilful blindness. The Weekend Australian.

Russell-Smith, J., Whitehead, P. \& Cooke, P. (2009). Culture, ecology and economy of fire management in north Australian savannas: Rekindling the Wurrk tradition. Collingwood, Vic.: CSIRO Publishing.

Salmon, M. \& Gerritsen, R. (2013). A more effective means of delivering conservation management: A 'new integrated conservation' model for Australian rangelands. The Rangeland Journal, 35(2), 225-230. doi.org/10.1071/RJ12080

Scambery, B. (2013). My country, mine country: Indigenous people, mining and development contestation in remote Australia. Centre for Aboriginal Economic Policy Research Series No. 33. Canberra, ACT: ANU E Press. doi.org/ 10.22459/CAEPR33.05.2013

Stanley, O. (2010). Mining and Aboriginal economic development: Expectations unfulfilled. In R. Gerritsen (Ed.), North Australian political economy: Issues and agendas (pp. 130-141). Darwin, NT: Charles Darwin University Press.

Stoeckl, N., Esparon, M., Farr, M., Delisle, A. \& Stanley, O. (2014). The great asymmetric divide: An empirical investigation of the link between Indigenous and non-Indigenous economic systems in Northern Australia. Papers in Regional Science, 93(4), 783-801. doi.org/10.1111/pirs.12028

Taylor, A., Bell, L. \& Gerritsen, R. (2014). Benefits of skilled migration programs for regional Australia: Perspectives from the Northern Territory. Journal of Economic and Social Policy, 16(1), Article 3. 
This text is taken from Leading from the North: Rethinking Northern Australia Development, edited by Ruth Wallace, Sharon Harwood, Rolf Gerritsen, Bruce Prideaux, Tom Brewer, Linda Rosenman and Allan Dale, published 2021 by ANU Press, The Australian National University, Canberra, Australia.

doi.org/10.22459/LN.2021.05 